\title{
Pastoral Subjugation in Hannah Kent's Burial Rites: A Biopolitical Outlook
}

\author{
--Pradeep Sharma \\ Associate Professor of English, \\ Ratna Rajya Laxmi Campus, \\ Kathmandu, Nepal. \\ Email: rrcampus72@gmail.com
}

https://doi.org/10.3126/litstud.v34i01.39536

\section{Abstract}

Hannah Kent's Burial Rites (2013) reflects the bare life of its protagonist, Agnes. She leads her Muselmann life from her outset of life. Grown up as foster child, she works as a farm maid whose rightful position is entirely ignored and eventually she is condemned to death. Natan molests her and she is banished from his home at night during snow fall when she demands her legal status at his home. Later she is accused of killing Natan and his friend. Before her execution, in order to tame and domesticate her, a priest is deployed who uses pastoral power, part of biopolitics that executes power over body. She unbuttons her pathetic life history along with her penitence. Finally, she leads a life of 'homo sacer' bearing the injustices like the superstes of holocaust and succumbed to condemnation.

Keywords: Bare life, Biopolitics, Subjugation, Homo Sacer, Superstes

Carl Schmitt, German jurist, in Political Theology views that modern secular state has had the foundation of theology for the systematic structure of the society. Precisely, Burial Rites (2013) by Australian novelist, Hanah Kent hinges on pastoral nurturing of Agnes who was thrown on the mercy of the parish when she was pretty young. Later she is condemned to death and Assistant Reverend Thorvardur Jonsson, a tyro priest is assigned to educate her spiritually and bring her under the mercy of Lord during her custodial stay at Reverend Jon Jónsson's home in Kornsa. In addition, he has to administer upon her Lord's words and inspire repentance before her execution. In the hostile milieu during her jail, she unbosoms her traumatic experience to that priest. Admittedly, whoever female characters are there in the novel go with under the effect of biopolitics; interlacing of life and politics (state power) whereby power manages life by executing state mechanisms. In this research, I argue that the execution of Agnes means a move taken by District Commissioner 
Reverend Björn Blöndal to subjugate other women who are likely to run riot against social institutions and hierarchy nurtured by sovereignty.

Further, I will explore how Agnes' condemned body fall under sovereign pastoral panopticon and her attuning with 'sovereign ban;' her subjugated position in her custodial life. Before she was found guilty of murder and after it she is subjected to condemned state that does not have any agency. She grows up with her step- father and half- brother. While staying at Natan's farm she is sexually exploited and when she demands her rightful position, she gets expelled from the room at night in frozen winter without clothes in her body. Nowhere she gets refuge save in the company with the cattle.

While investigating the use of power over Agnes, Blöndal exercises juridico- pastoral power to retain the regimes of truth over her. The regime of truth refers historically specified apparatuses like family, school, and church which produce discourse that is deemed to be general truth in a specific space and time known as heterotopia. The centrality of the discussion revolves around the status of Agnes before the sovereign's exercise of power. Jane Jakeman reviews in Independent also hints the use of pastoral power. She notes: "Chained and half-starved, Agnes Magnusdottir is initially regarded as a monster, but gradually the mother of the family and the young priest who attends her, come to realise that the story was far more complex than the facts presented in court'In her case there is the suspension of law especially bios, known as fundamental rights that Agamben characterizes as the situation of abandonment, a bare life like of the bandits used to pursue in classical time. This is how she is produced as a liminal-figure of the human and animal. Undeniably this situation of Agnes mirrors and contributes to Foucauldian concept of biopolitics and Agamben's thesis on homo sacer.

Equally important reading of Paramita Ayuningty from gender violence under the patriarchal normativity also centers on the injustice that dramatizes the bitter feeling of the people against Agnes. She contends:

In the beginning, each of them sees Agnes with negative stereotypes. Tóti sees Agnes as a lost child that needs to be saved, while Margrét says that she is the Devil's child .... On the other hand, there are other characters who keep stereotyping Agnes as a wicked woman who does not deserve pity and compassion, such as the District Commissioner Björn Blöndal and Margrét's neighbor, Róslin. They also judge Agnes as a rebelling woman. (78) 
Ayuningty argument also leads to the use of biopolitics. When the court declares Agnes a culprit, she is made more docile, however people consider her a murderer equal to devil who is also a rebel.

On the prima facie, Foucault's biopolitics concerns with subjectification of population after the end of sovereign governmentality in Europe. The advent of biopolitics along with neoliberalism thereby treated populations as object and subject of politics. Further his concept of biopolitics goes with how power shapes the life of an individual of populations. It is power over life that subscribes "governmental practice by phenomena characteristics of a set of living forming a population:

health, hygiene, birth rate, life expectancy, race. . (Birth of Biopolitics 317). The governmental exertion of power over the populations in terms of their growth from prenatal to death that the regime supervises by deploying technologies of power. One of them is pastoral power which is designed to govern or guide people's conduct in the way a shepherd tames his flock. Namely, pastoral power goes with theology that helps an individual for self-disciplining and being a docile person. Agnes is subjected to go under the canopy of Christian pastorate in Burial Rites before she gets killed.

This is politics induced idea that molds one's daily conduct and also helps to exercise redemptive role in his life. Given anecdote of letter sent by Björn Blöndal to Assistant Reverend Thorvardur Jónsson in Burial Rites mirrors the use of pastoral power to groom Agnes spiritually and make her docile while her custodial stay at Kornsá. Further the letter contains: "She (Agnes) is discontent with her current spiritual administrator...you must administer God's word and inspire repentance and an acknowledgement of Justice" (Burial Rites 7). Here is the indication of the use of pastoral power to guide the condemned murderer, Agnes and make her follow the law by means of the 'regime of truth;' discourse that is in use in society as per the ruler's design.

Ambiguity lies in Foucauldian analysis of power when he elaborates both positive and controlling effect of power. He expounds: "Power that exerts a positive influence on life that endeavours to administer, optimize, and multiply it, subjecting it to precise controls and comprehensive regulations" (History of Sexuality 137). To him in order to administer the individual or the group of people regime needs to apply disciplinary mechanism along with the rules. Disciplinary power is not always positive. Later he adds ." . numerous and diverse techniques for achieving the subjugation of bodies and the control of populations" (History of Sexuality 140) . This proves the fact that biopower manipulates 
people and if needed it subjugates their body. The custodial holding of Agnes at Kornsá decries the hostile reaction of the host family and her animal like position prior to her coming there. Agnes reveals her hade like life as:

This is no life; waiting in darkness, in silence, in a room so squalid I have forgotten the smell of fresh air. The chamber pot is so full of my waste that it threatens to spill if someone does not come and empty it soon ... They left me alone without the light and there is no means to measure the hours, no way to mark the day from the night. (Burial Rites 18)

Agnes narrative projects on how she was treated in Stora-Berg when the local court found her guilty in the murder of two men. This site where she is assigned to for her custodial holding equalizes with the barn or cowshed. It is a violence over body.

There is violence upon her body: "men sometimes tie my legs together in the evening as they do with the forelegs of the horses. . . I become more like an animal to them" (29) and ." . .mark here, bruises, blossoming like star clusters under the skin, black and yellow smoke under the membrane ... I am tied like a lamb for slaughter" (35-36). The animal like bondage sharply delineates how miserably Agnes is subjugated in her unwilling involvement in the crime. Danijela Petkovic also finds the same stand. She confirms:

Drawing consistent parallels between the convicted woman and animals lambs in the "killing pen" in particular - Hannah Kent problematizes longstanding human institutions and traditions such as law, death sentence, patriarchy and the (ab)use of animals. Moreover, she demonstrates that "the animal" and "the criminal" are mutually supportive socio-legal constructs realised on the bodies of sentient beings via identical technologies. (74)

Her reading passes a new insight of treating the criminal and animal is equal. In so doing the regime uses the same technologies of power.

Indeed, she had stabbed Natan because he was already been severely wounded by Fridrik whose fiancée Natan had possessed. Besides he was in acute pain and dying slowly. To relive him from his pain she used euthanasia which turned out to be her crime. She is like a scapegoat for sacrifice. The lamb for slaughter is an allegorical use from the Bible Isaiah 53:7 justifies that Agnes is a sole victim a subjugated women who can be juxtaposed with Muselmann, a person of no value subjected or reduced to zero state but who can provide the evidences of physical and mental injustice. Ostensibly, Agnes is the bearer of state induced atrocity upon whom any brutality can be done but it cannot expressed the violence on her. 
Notably, in Means without End, Agamben elaborates zoe as zoological life equal to animal and bios as biographical body that speaks and is consigned rights. Further in 'form -of- life as political life,' he imbibes Walter Benjamin's "bare life," life without political and cultural rights excluded from city in ancient system. Agnes in Burial Rites meets with this animal status as she is an outcast of an alleged crime. Hannah Arendt names it as 'outlawry' and expounds:

An outlaw, in the sense intended by Arendt (she uses the phrase "outside the pale of the law" instead of 'outlaw') is someone, such as an exile or refugee, who is not recognized by the law; an outlaw lacks legal status unless brought into the law, either through citizenship or criminalization. (qtd. in Bunch 9) Sovereignty keeps a group of people outside the law by categorizing them as good and bad. In assimilating Foucault, Agamben reiterates that with the rise of totalitarian regimes in the $20^{\text {th }}$ century, the state of exception is steadily becoming the rule which the subjects customize. He critiques: "Exception and example are correlative concepts that are ultimately indistinguishable" (Homo Sacer 22). This is how when exception turns out to be general law, there starts 'bestialization'(terms used in Agamben's The Open: Man and Animal) of subjects by the state power.

The violence over body, according to Foucault can be justified in term of safe guarding 'entire populations' rather than defending 'the name of sovereign'(History of Sexuality 137). It seems the violence perpetrated over Agnes through judicial machinery of the sovereignty that ultimately turns her into a superstes; who bears the brutality of the power abuse from the beginning to the end. In this state Agnes is kept aloof and alienated from her political rights. Further this infliction of legal violence over her definitely has a political motive which Blöndal elaborates: "I will not deny that the execution also brings with it an opportunity for our community to witness the consequences for grave misdemeanor" (Burial Rites 17). His statement overtly indicates the hidden interest of the regime at its use of power which works in two folds; one is it executes law to mitigate the crime and the other is that it helps to discipline rest of the populations and stops them from violating the laws. This is how it sets up the regime of truth in the given space and time so that the populations remains manageable. Hinting out the punitive nature of the regime, Foucault exposes: "One had the right to kill those who represented a kind of biological danger to others" (History of Sexuality 138). The sovereignty justifies it on the ground of safeguarding the populations and retains its highest prerogatives of power in putting people to death if felt threats. 
Equally important is the reading of Ben Golder who remaps Foucauldian concept of pastoral power as: "The Christian pastorate, that "art of conducting, directing, leading, guiding, taking in hand, and manipulating men . . . collectively and individually throughout their life and at each moment of their existence" developed into modern forms of governmentality" (qtd. in Golder 167) . His summation of Foucault's pastoral power seems to be the part of biopower that guides populations both collectively and individually. In particular the appointment of the priest to look after Agnes in Burial Rites is not to ensure her heavenly abode after her death but to make her docile and tame her during her cell life. Important to realize is that exercise of power over life has the bull's eye to modify human life in order for rendering it more fruitful and manageable. It also helps to make body succumb and be loyal as well as useful for sustaining social institutions intact. In Burial Rites Agnes is tamed out of pastoral power. She finds herself guilty of killing and as penance she starts helping with the domestic chores while she is awaiting for her death penalty. Primarily, power over life, on the one hand, consists in subjectivation through discipline and surveillance, and on the other, in regulation and manipulation of the overall qualities of population. Foucault elaborates:

In concrete terms, starting in the seventeenth century, this power over life evolved in two basic forms; these forms were not antithetical, however; they constituted rather two poles of development linked together by a whole intermediary cluster of relations. . . The disciplines of the body and the regulations of the population constituted the two poles around which the organization of power over life was deployed. (History of Sexuality 139).

Foucault's primarily focuses on human body as a machine that is more productive and efficient under surveillance and human body as species that undergoes with biological processes. On both cases body as machine and body as species there is power over life.

Foucault has also reductionist view of power. He states: "sovereign has a right of life and death means that he can, basically either have people put to death or let them live. . . The right of life and death is exercised in an unbalanced way: the balance is always tipped in favour of death" (Society Must Be Defended 240). His point is to exhibit the centrality of power in Sovereign governmentality that besieges the right of life and death either 'by some threat or by need.' And ultimately, the sovereignty deploys the power: "to take life or let live" (Society Must Be Defended 241) for creating titular person. Whereas after the great transformation under liberalism in Europe in the nineteenth century that regime's undemocratic 
absolute authority of taking life and letting one die turned into: "'make" live and "let" die" (Society Must Be Defended 241). Agnes is made live with repentance before she gets hung publicly.

It is the statecraft of using power over the denizens by means of liberalism but fundamentally there is no difference between new and old regimes. This leads David Ebert to observe and sum up the nature of democratic states while going through Agamben. He asserts: "modern totalitarian states are in the disguise of democracy" (YouTube 8:18). It is in the sense that the rights of citizens are frequently suspended during the statecraft. Whether or not democratic regime goes with reductionist view of power to exclude the denizens from their rightful position. By and large its locus lies in the process of turning the subjects into homo sacer, who has no lawful position save being the means of the regime. Before her indictment Agnes was the outcast. There is sovereign ban on her life. Nevertheless Inga, her daring mother teaches her reading the Bible in the absence of her step-father. Agnes recounts it as: "She (Inga) saw I had an aptitude for learning and taught me as best she could. He (Inga's husband) didn't like me reading and writing either. . . Vulgar for a girl, he said" (142). This shows her outlawry from the very onset of her life. She has been perpetually ripped off the basic needs of life. What is ensured for her is to copulate with Natan when she was his farm maid and meet exile when she reminds Natan his moral duty. In fact, he treats her as if she is his concubine. The zoé, life of animal or domesticated life of feeding body and enjoying sexual life is ensured not the speaking life of bios to Agnes. She recalls her love making with Natan and her dismissal from his home after being reduced as a sex object: you are a cheap sort of woman ... He dragged me down pushed me over to the doorstep. I tripped on the ledge and went sprawling into the snow, naked

... He had slammed the door in my face" (288). In the past this type of molestation was apt only to the person who had no agency. As Agnes was the outcast from her birth, Natan, a herbalist having the privilege of power enjoys the freedom of sexuality with many women. As Agnes reminds him not to do so he expels her nude from his home in the snow at night. Her nudity metaphorically goes with her bare life as envisioned by Agamben. Therefore, she is projected as a homo sacer.

While summing up Foucauldian biopolitics in Homo Sacer, Agamben draws an anology between power and man's life: "the growing inclusion of man's natural life, zoé ('bare life') in the mechanisms and calculations of power" (119). Most importantly, his stand is to excavate the politicization of life. He also exposes the entrapment of zoé (ikos) 
belonging to subsistence and reproduction excluded from polis (bios), under totalizing social, legal, and cultural mechanism. Notably, the inclusion of bare life in politics is the base of the production of bipolitical body of sovereign power. For Agamben, in modern Western politics there is not categorical pair of friend/ enemy but that of bare life / political existence, zoé/ bios, exclusion/ inclusion thereby man maintains himself in relation to that bare life in an inclusive exclusion (Homo Sacer 8). Thus, life falls in-between the indistinction of inclusion and exclusion shortly after it is smeared with politics.

In Burial Rites when the trial undergoes to declare Agnes a murderer, her statement is unheard of. Indeed, she has involved herself in the killing of Natan and Pétur out of benign purpose. Conversely, Agnes'indictment proves to be inclusive exclusion to make her a nonperson whose is subjected as condemned whose redemption via Christian pastorate care that has been sought in the novel. She comments: "During the trial they didn't let me say what happened in my own way . . . . They wrested my statement of that night and made me malevolent" (100). She sharply responds on the bullying nature of the regime through judico-politics to turn her into condemned and abject person. It proves the controlling nature of the sovereignty to exclude the denizens from their rights. Ironically the deployment of a young priest for her redemption is a use of power technology to manage her until her killing.

Agamben reviews on Foucauldian processes of subjectivization. He asserts"in the passage from the ancient to the modern world, bring the individual to objectify his own self, constituting himself as a subject and, at the same time, binding himself to a power of external control" (Homo Sacer 119). He thoroughly elaborates Foucault's view on the subjectivation of a person to relegated body by state mechanism which Schotten in "Against Totalitarianism: Agamben, Foucault, and the Politics of Critique" surveys:

Agamben agrees with Foucault that modern politics is biopolitics, but disagrees that biopolitics is distinctly modern. Instead, Agamben argues that biopolitics is as old as politics itself, because politics - at least in its Western version - is effectively a politics of sovereignty, and "sovereignty, in Agamben's view, is inherently biopolitical. (156)

Schotten expounds the juxtaposition and contrast between Agamben (biopolitics was as old as sovereignty) and Foucault (biopolitics emerges after the relegation of sovereignty) in the inception of biopolitics over human body that curtails the rights of citizens. Anyway the concerns of 
Agamben and Foucault are implied in case of Agnes in Burial Rites in which she is made docile and succumb to the unjust law.

Largely, in Agamben's oeuvre biopolitics involves in the production of bare life or homo sacer. He assumes that in the past, homo sacer was an exceptional category who can be killed beyond impunity whereas today, everyone is homo sacer (Muselmann) because Agamben argues that the exception, suspension of law, turns to be the rule and it deeply dovetails with politics. Agnes in Burial Rrites turns out to be a case study of bare life who falls under exclusion from law when she used euthanasia to dying Natan.

Burial Rites also forwards the issue that the regime has used pastoral power on the body of already condemned criminal. It is to nurture Agnes, the murderer, so that she could be tamed and manageable until her execution in public space. When Assistant Reverend Thorvadur Jónsson (Toti) meets Agnes, he finds her in the redemptive 'for-of-life' which in Agamben's terms cannot be separated between zoe and bios. Like a bandit she has been shunned and alienated from her bios, political rights. In a nutshell, she falls under sovereign ban. With this Agamben demystifies the use of power under the veil of biopolitics that takes away civil rights of the people. But in the meantime, the regime succeeds in creating the discourse to hegemonize the people by means of power. Above all, in modern political system biopolitics is a power that 'fosters and enhances life' and creates 'a docile body that it needs' by managing the populations via regulating birth rate and promoting public health unlike pre-modern regime which usurped life for death.

In the light of Agnes' abandoned life, redemption and docility has been sought through the redemptive process thereby she remains under the supervision of Jonsson, the Baptist. Consequently, her new form of life is away from the law, she is abjected but has been made docile so that she would not harm other. How she succumbs and feels subjugated under the spell of pastoral power is that she realizes: "They said I must die. I stole the breath from the man and now they must steal mine" (1). It proves that she has already been subjected to adhere with the extant law. This one is the outcome of the company and tutoring of Toti who boasts: "God has chosen me to shepherd you" (98). This one is the most compelling evidence of pastoral power that befits her to groom Agnes. Together with it, Margret's remark "You can prove your penitence by working like a dog" (74) markedly decries the strength of pastoral power in disciplining Agnes who helps milking the sheep and helping with domestic chores although she is shunned by host family during her custodial stay. 
Putting Agnes to death celebrates expressively the statecraft of pastoral power that makes Agnes go with law, docile. On the other hand, Natan's womanizing character has been indirectly celebrated because it supports the regime by using prerogative power to turn the female into an abject. Both the state and Natan subjugate and exploit her. The irony for Agnes is that when she demands her rightful position, she is outlawed and the state puts her into incarceration and finally kills her. This totalizing biopolitics, after all, turns her into 'homo sacer' and kills her in order to fortify state apparatuses.

\section{Works Cited}

Agamben, Giorgio. Homo Sacer: Sovereign Power and Bare Life. Trans.DanielHeller- Roazen. SUP, 1995.

---. The Open: Man and Animal. Translated by Kevin Attell and edited by WernerHamacher, Satnford UP,2004.

---.Means Without Ends: Notes on Politics. Translated by Vincenzo Binetti andCesare Casarino, UOM Press, 2000. Ayuningtyas, Pramita. "Deconstructing the Stereotypes of Women through femalevoice in Burial Rites."Jurnal Lingual Cultura, vol.9, no.2, Nov. 2015,pp.7580.

Bunch, Mary J. "Outlawry and the Experience of the (Im)possible: DeconstructingBiopolitics." Dissertation. University of Western Ontario, 2010.

David, Ebert. "Giorgio Agamben's Homo Sacer."YouTube, 3.16.2016,youtube.com/watch?v=y7T2weikFPo.

Foucault, Michel. The Birth of Biopolitics: Lectures at the College de France1978-79. Translated by Graham Burchell and edited by Michael Senellart. Picador, 2008.

---. The Will to Knowledge. History of Sexuality: Vol.1. Translated by Robert Hurley.Penguin Books, 1998.

---. Society Must Be Defended. Translated by David Macey. Penguin Books, 2003.

---. Security, territory and population, edited by Graham Burchell, Palgrave, 2009.

Golder, Ben. "Foucault and the Genealogy of Pastoral Power."Radical PhilosophyReview, vol. 10, no. 2, 2007, pp. 157176.http://ssrn.com/abstract=1348831

Jakeman, Jane. Book Review: Burial Rites by Hannah Kent. Independent.29 Oct.2013. Independent.co.ukpicador-ps12-998911521.htmlKent, Hannah. Burial Rites. Picador, 2013. 
Petkovic, Danijela. "Like a lamb Ripe for Slaughter: Female Body, Law andDomestic Animals in Hannah Kent's Burial Rites"De Gruyter Open. pp. 74-90. DOI: 10.1515/genst-2017-0006

Schotten, C. Heike. "Against Totalitarianism: Agamben, Foucault, and the Politics ofCritique."Foucault Studies, vol. 20, 2015, pp. 155-179. 